\title{
Evaluasi Desain Terminal Penumpang Bandar Udara Sentani Jayapura Provinsi Papua
}

\author{
Samin $^{* 1}$, Alifia Dian Khoiriani², Alik Ansyori Alamsyah ${ }^{3}$ \\ ${ }^{1,2}$ Universitas Muhammadiyah Malang, Kampus III Jl. Raya Tlogomas No.246, Malang 65144 \\ ${ }^{3}$ Program Studi Teknik Sipil, FT UMM, Malang \\ Email: *11samin.itbs3@gmail.com, ${ }^{2}$ alifiadiankhoiriani@gmail.com, ${ }^{3}$ alik.syah@yahoo.com
}

Received 20 August 2021; Reviewed 20 October 2021; Accepted 15 November 2021

Journal Homepage: http://jurnal.borneo.ac.id/index.php/borneoengineering

\begin{abstract}
Sentani Airport serves public using air transportation with increasing people mobility conditions because Jayapura is the National Activity Center, so it causes frequent accumulation of passengers in the terminal area especially during peak hours. To determine the effectiveness of the terminal in accommodating the flow of passenger movement, it is necessary to evaluate the terminal design of Sentani Airport. The method used is to calculate the number of PWS with passenger distribution patterns, calculate the standard area of terminal capacity using references from SNI 03-7046-2004 and SKEP 77/VI/2005, calculate the terminal LOS with IATA standards, measure the airport service standards based on PM 178 of 2015, processing passengers' perceptions with IPA and QFD methods and forecasting with simple linier regression. From the analysis, Sentani Airport terminal gives passengers mobility with low service performance value, so it is rated as less optimal. In addition, the limited availability of several facilities causes the passengers feeling less comfortable. Thus, it is necessary to re-design the passenger terminal area and re-management the facilities according to Angkasa Pura standards.
\end{abstract}

Keywords: Sentani Airport, Capacity, Services, IPA, QFD.

\begin{abstract}
Abstrak
Bandar Udara Sentani melayani masyarakat pengguna jasa transportasi udara dengan kondisi mobilitas yang terus meningkat terutama Kota Jayapura menjadi Pusat Kegiatan Nasional, sehingga sering terjadi penumpukan penumpang di area terminal apalagi pada waktu sibuk. Untuk mengetahui efektivitas terminal dalam mewadahi arus pergerakan penumpang, perlu dilakukan evaluasi terhadap desain terminal Bandar Udara Sentani. Metode yang digunakan yaitu menghitung jumlah PWS menggunakan pola distribusi penumpang, menghitung standar luas kapasitas terminal dengan acuan dari SNI 03-7046-2004 dan SKEP 77/VI/2005, perhitungan LOS terminal dengan standar IATA, pengukuran standar pelayanan jasa bandara berdasarkan PM 178 Tahun 2015, pengolahan persepsi penumpang dengan metode IPA dan QFD serta peramalan dengan regresi linier sederhana. Dari hasil analisa, terminal Bandara Sentani memberikan akses pergerakan penumpang dengan nilai kinerja yang rendah, sehingga hal itu dinilai kurang optimal. Selain itu, terbatasnya ketersediaan beberapa fasilitas menyebabkan penumpang merasa kurang nyaman. Dengan demikian, perlu dilakukan perencanaan ulang area terminal penumpang serta pengelolaan kembali sarana kelengkapan sesuai dengan standar Angkasa Pura.
\end{abstract}

Kata Kunci: Bandar Udara Sentani, Kapasitas, Pelayanan Jasa, IPA, QFD. 


\section{Pendahuluan}

Bandar udara adalah suatu wilayah khusus yang terletak di daratan maupun perairan yang mempunyai batas-batas tertentu untuk pesawat secara khusus melakukan pendaratan dan lepas landas, menaikkan dan menurunkan penumpang, keluar masuknya barang/muatan dari pesawat udara, tempat berlangsungnya pergantian dari beberapa moda transportasi dengan sarana keamanan dan keselamatan penerbangan serta fasilitas pendukung lainnya (Kementerian Perhubungan Republik Indonesia, 2015). Menurut UU No. 1 Tahun 2009 pasal 219 ayat 1 tentang Penerbangan, badan usaha atau unit penyelenggara bandar udara wajib menyediakan fasilitas bandara yang memenuhi persyaratan keselamatan dan keamanan penerbangan serta pelayanan jasa sesuai dengan standar yang telah ditetapkan (Presiden Republik Indonesia, 2009). Umumnya, masalah yang sering dihadapi dalam merencanakan sebuah terminal bandara yaitu kapasitas yang berkaitan dengan desain optimal dan besar perluasan untuk area-area dalam terminal dengan ketidakpastian tingkat permintaan serta biaya perluasan di masa yang akan datang (Clarke, Jhonson, Solak, \& B, 2009). Untuk memperoleh nilai standar persyaratan teknis fungsional fasilitas darat bandar udara, digunakan satuan dari banyaknya jumlah penumpang yang dapat dilayani dengan luasan yang cukup dan terjamin untuk masing-masing sarana sehingga dapat memenuhi aspek efektivitas, kecepatan, kenyamanan, keselamatan, keamanan, dan kelancaran penerbangan (Peraturan Direktur Jendral Perhubungan Udara, 2005).

Bandar Udara Sentani mengalami peningkatan mobilitas baik penumpang maupun pesawat setiap tahunnya. Perkembangan jumlah penduduk yang pesat, kondisi terminal yang kurang memadai serta fungsi Kota Jayapura sebagai Pusat Kegiatan Nasional (PKN) (Pusat Pengembangan Kawasan Perkotaan, 2017) menyebabkan sering terjadi penumpukan penumpang di area terminal terlebih pada waktu sibuk. Selain itu, terdapat beberapa kekurangan yang dirasakan oleh penumpang baik dari segi fasilitas maupun pelayanan yang diberikan oleh Bandara Sentani.

Berkaitan dengan permasalahan tersebut, perlu dilakukan evaluasi desain terminal penumpang Bandar Udara Sentani untuk mengetahui kondisi dan tingkat pelayanan eksisting terminal tersebut. Penelitian ini menggabungkan analisis perhitungan kapasitas dengan pengolahan persepsi penumpang (kepentingan/harapan) sebagai alternatif penunjang dalam pengembangan/perbaikan fasilitas terminal Bandara Sentani serta bentuk pembaharuan atas evaluasi desain sebuah terminal yang tidak hanya dilihat dari sisi luas bangunananya melainkan meninjau harapan pengguna jasa.

Hasil dari evaluasi desain terminal penumpang Bandar Udara Sentani ini dapat digunakan sebagai pertimbangan rekomendasi upaya perbaikan untuk meningkatkan kinerja bandara tersebut.

\section{Metode Penelitian}

Evaluasi desain terminal penumpang Bandar Udara Sentani dimulai dengan analisis jumlah penumpang menggunakan metode pola distribusi penumpang untuk mengetahui lebih detail banyaknya penumpang kondisi peak hour (Riki Tri Alfian \& Widyastuti, 2013), perhitungan standar luas dan nilai LOS terminal bandara digunakan untuk mengetahui kemampuan terminal dalam mewadahi pergerakan penumpang dengan acuan dari SNI 03-7046-2004 (Badan Standardisasi Nasional, 2004) dan SKEP 77/VI/2005, serta perhitungan nilai Level Of Service (LOS) dengan standar dari IATA (International Civil Aviation Organization, 2000) (Sompotan, 2018) dan (Bakri \& Christin, 2019). Selain itu, untuk mengukur standar pelayanan jasa bandar udara menggunakan pedoman terbaru yakni PM 178 Tahun 2015 (Menteri Perhubungan Republik Indonesia, 2015), dan pengolahan persepsi penumpang berdasarkan kepentingan dan kinerja/kepuasan dengan penggabungan metode Importance Performance Analysis dan Quality Function Deployment untuk mengetahui harapan perbaikan dari penumpang terhadap tingkat pelayanan jasa yang masih dalam kondisi kurang baik/buruk serta respon penanganan dari pengelola bandar udara untuk meningkatkan kinerjanya (Mariana, Sulistio, \& Arifin, 2015), (Wahyudi, Arifin, \& Wicaksono, 2016), dan (Arifin, 
Sulistyo, \& Djakfar, 2015). Setelah melakukan re-design terminal, dilakukan peramalan dengan metode regresi linier sederhana untuk mengetahui kebutuhan rencana kapasitas terminal dalam jangka waktu dekat (Tulungen, 2016). Alur penelitian dapat dilihat pada Gambar 1.

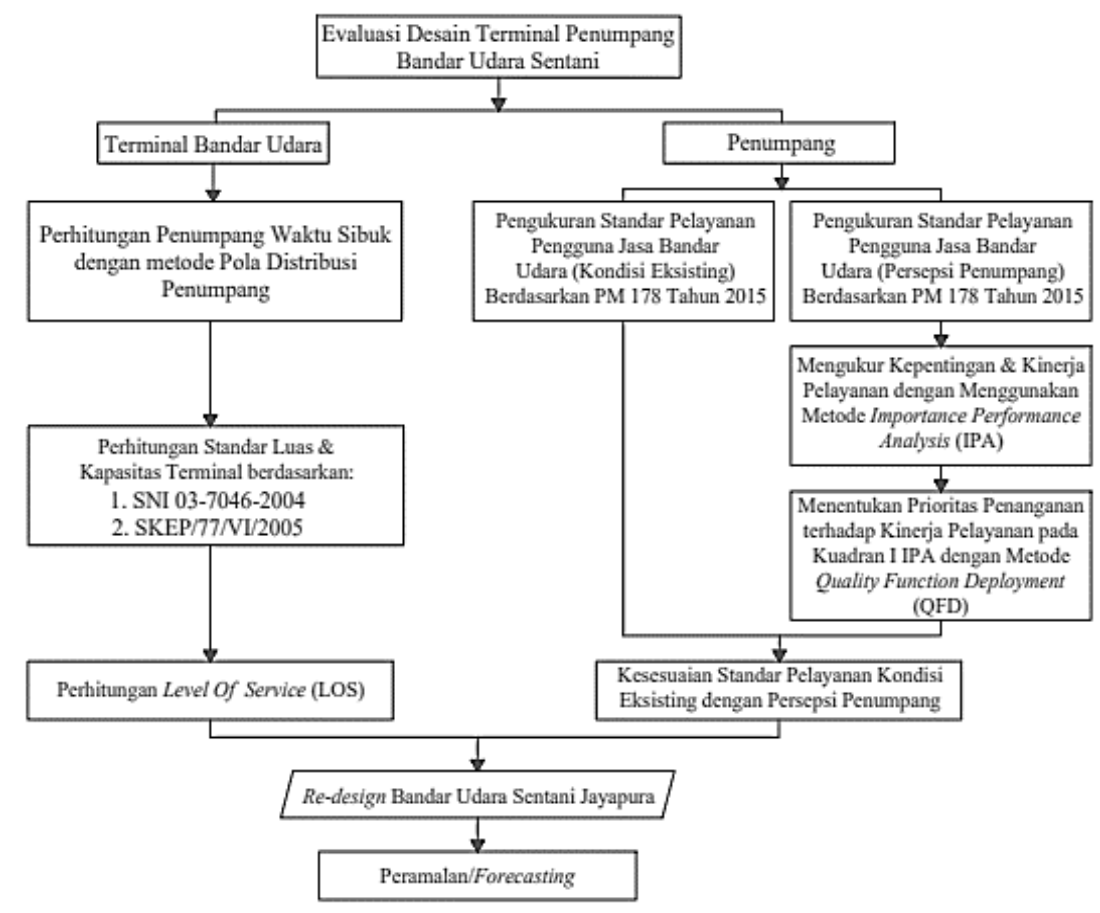

Gambar 1. Diagram Alir Penelitian

\section{Hasil dan Pembahasan}

\subsection{Perhitungan Penumpang Waktu Sibuk (PWS) dengan Metode Pola Distribusi Penumpang}

Berdasarkan perolehan data dari PT. Angkasa Pura I, Bandar Udara Sentani, jumlah pergerakan penumpang tertinggi terjadi pada tanggal 29 Februari 2020 dengan rincian sebagai berikut:

PWS Kedatangan $(05.55-10.07$ WIT $) \quad=3187$ penumpang.

PWS Keberangkatan $(07.39-10.14$ WIT $)=3082$ penumpang.

PWS Keberangkatan Ruang Tunggu:

Lantai $1(07.11-11.47 \mathrm{WIT}) \quad=674$ penumpang.

Lantai $2(07.39-10.14 \mathrm{WIT}) \quad=2227$ penumpang.

\subsection{Perhitungan Standar Luas Terminal Penumpang Bandar Udara}

Standar luas terminal penumpang Bandar Udara Sentani dihitung dengan ketetapan dari menteri perhubungan RI (PM 178 Tahun 2015), perhitungan luas terminal penumpang sebagai berikut:

$\mathrm{A}_{\text {Teoritis }}=\mathrm{PWS}_{\text {Domestik }} \times 14 \mathrm{~m}^{2} /$ penumpang

$=6269 \times 14 \mathrm{~m}^{2} /$ penumpang

$=87766 \mathrm{~m}^{2}$

Setelah mengetahui luas teoritis terminal penumpang, dilakukan perhitungan kapasitas terminal penumpang Bandar Udara Sentani dengan hasil yang dicantumkan dalam Tabel 1. 
Tabel 1. Hasil Perhitungan Kapasitas Terminal Penumpang Bandar Udara Sentani

\begin{tabular}{clcc}
\hline No. & \multicolumn{1}{c}{ Fasilitas } & Hasil Analisis & Kondisi Eksisting \\
\hline 1. & Curb Keberangkatan & $2900 \mathrm{~m}^{2}$ & $1258 \mathrm{~m}^{2}$ \\
2. & Curb Kedatangan & $3000 \mathrm{~m}^{2}$ & $422 \mathrm{~m}^{2}$ \\
3. & Hall Keberangkatan & $8154 \mathrm{~m}^{2}$ & $2770 \mathrm{~m}^{2}$ \\
4. & Hall Kedatangan & $6836 \mathrm{~m}^{2}$ & $1163 \mathrm{~m}^{2}$ \\
5. & Pemeriksaan Security (Terpusat) & $12 \mathrm{unit}^{2}$ & $2 \mathrm{unit}$ \\
6. & Check-in Area & $1023 \mathrm{~m}^{2}$ & $1374 \mathrm{~m}^{2}$ \\
7. & Counter Check-in & $136 \mathrm{counter}^{2}$ & 30 counter \\
8. & Area Custom Immigration Quarantine & $956 \mathrm{~m}^{2}$ & $67,84 \mathrm{~m}^{2}$ \\
9. & Ruang Tunggu Keberangkatan Lt. 1 & & \\
& Luas Gedung & $740 \mathrm{~m}^{2}$ & $1214 \mathrm{~m}^{2}$ \\
& Kapasitas Kursi & $674 \mathrm{pnp}^{2}$ & $312 \mathrm{pnp} .^{2}$ \\
10. & Ruang Tunggu Keberangkatan Lt. 2 & & \\
& Luas Gedung & $2448 \mathrm{~m}^{2}$ & $2208 \mathrm{~m}^{2}$ \\
& Kapasitas Kursi & $2227 \mathrm{pnp}^{2}$ & $1148 \mathrm{pnp} .^{2}$ \\
11. & Gate Hold Room & $189 \mathrm{~m}^{2}$ & $139 \mathrm{~m}^{2}$ \\
12. & Toilet Keberangkatan & $678 \mathrm{~m}^{2}$ & $274,34 \mathrm{~m}^{2}$ \\
13. & Toilet Kedatangan & $701 \mathrm{~m}^{2}$ & $193 \mathrm{~m}^{2}$ \\
11. & Baggage Claim Area & $3155 \mathrm{~m}^{2}$ & $1988 \mathrm{~m}^{2}$ \\
12. & Baggage Claim Device & $11 \mathrm{unit}^{2}$ & $3 \mathrm{unit}$ \\
\hline
\end{tabular}

Sumber: Hasil Perhitungan (2021).

Pada Tabel 1, diketahui bahwa sebagian besar fasilitas yang ada pada terminal penumpang Bandar Udara Sentani telah melampaui kapasitas kondisi eksisting pada saat ini, sedangkan untuk fasilitas lainnya seperti luas check-in area dan luas ruang tunggu keberangkatan lantai 1 pada kondisi aktual masih maksimal dalam memenuhi dan menjadi akses pergerakan penumpang khususnya pada waktu sibuk operasional terminal.

\subsection{Perhitungan Luas Operasional Terminal Penumpang Bandar Udara}

Luas total operasional terminal penumpang Bandar Udara Sentani diperoleh dari hasil penjumlahan keseluruhan luas area operasional dengan uraian seperti yang ditunjukkan pada Tabel 2,

Tabel 2. Luas Operasional Terminal Penumpang

\begin{tabular}{ccc}
\hline No. & Fasilitas & Luas Area $\left(\mathbf{m}^{\mathbf{2}}\right)$ \\
\hline 1. & Curb Keberangkatan & 2900 \\
2. & Curb Kedatangan & 3000 \\
3. & Hall Keberangkatan & 8154 \\
4. & Hall Kedatangan & 6836 \\
6. & Check-in Area & 1023 \\
7. & Area Custom Immigration Quarantine & 956 \\
8. & Ruang Tunggu Keberangkatan Lt. 1 & 740 \\
9. & Ruang Tunggu Keberangkatan Lt. 2 & 2448 \\
10. & Gate Hold Room & 189 \\
11. & Toilet Keberangkatan & 678 \\
12. & Toilet Kedatangan & 701 \\
13. & Baggage Claim Area & 3155 \\
\hline & Total & $\mathbf{3 0 7 8 0}$ \\
\hline
\end{tabular}

Sumber: Hasil Perhitungan (2021). 
Berdasarkan uraian Tabel 2, diperoleh hasil untuk luas kebutuhan operasional terminal penumpang Bandar Udara Sentani agar maksimal dalam menampung penumpang pada waktu sibuk (peak hour) adalah $30780 \mathrm{~m}^{2}$.

\subsection{Perbandingan Luas Terminal Penumpang Bandar Udara}

Setelah memperoleh total luas operasional, maka dapat dihitung nilai bersih luas operasional terminal penumpang Bandar Udara Sentani dengan mempertimbangkan gudang perawatan/peralatan terminal, fasilitas penunjang terminal atau HVAC (Heating, Ventilation, and Air Conditioner) dan struktur gedung dengan perhitungan seperti pada Tabel 3,

\section{Tabel 3. Luas Operasional Terminal Penumpang}

\begin{tabular}{ccc}
\hline No. & Fasilitas & Luas Area $\left.\mathbf{~ m}^{\mathbf{2}}\right)$ \\
\hline 1. & A $_{\text {Gedung }}$ & 923,4 \\
2. & $\mathrm{~A}_{\text {Total 1 }}$ (Total Luas Operasional $\left.+\mathrm{A}_{\text {Gedung }}\right)$ & 31703,4 \\
3. & $\mathrm{~A}_{\mathrm{HVAC}}$ & 4755,51 \\
4. & $\mathrm{~A}_{\text {Total 2 }}\left(\mathrm{A}_{\text {Total 1 }}+\mathrm{A}_{\mathrm{HVAC}}\right)$ & 36458,91 \\
5. & $\mathrm{~A}_{\text {Struktur }}$ & 1822,95 \\
6. & $\mathrm{~A}_{\text {Total Operasional }}\left(\mathrm{A}_{\text {Total 1 }}+\mathrm{A}_{\text {Total 2 }}\right)$ & 38282 \\
\hline
\end{tabular}

Sumber: Hasil Perhitungan (2021).

Dari hasil perhitungan dalam Tabel 3, dilakukan perbandingan luas operasional dengan luas teoritis terminal penumpang pada saat ini yaitu $A_{\text {Operasional }}=38282 \mathrm{~m}^{2}$ dan $A_{\text {Teoritis }}=87766 \mathrm{~m}^{2}$. Dari nilai tersebut, diperoleh $\mathrm{A}_{\text {Teoritis }}>\mathrm{A}_{\text {operasional, }}$, sehingga luas teoritis terminal penumpang Bandar Udara Sentani akan dibandingkan dengan luas eksisting yaitu $A_{\text {Teoritis }}=87766 \mathrm{~m}^{2}$ dan $A_{\text {Aktual }}=14873 \mathrm{~m}^{2}$. Berdasarkan perbandingan tersebut, luas teoritis terminal penumpang > luas eksisting yang berarti kondisi Bandar Udara Sentani Jayapura sesuai perhitungan pada saat ini masih kurang maksimal jika harus menampung jumlah penumpang datang maupun berangkat pada waktu sibuk (peak hour).

\subsection{Perhitungan Level of Service (LOS) Terminal Bandar Udara}

Dalam mengukur tingkat pelayanan jasa pada terminal penumpang Bandar Udara Sentani, Seperti Pada Tabel 4 dilakukan perhitungan menggunakan standar dari IATA (International Air Transport Association),

Tabel 4. Level of Service Fasilitas Terminal Penumpang Bandar Udara Sentani

\begin{tabular}{lcc}
\hline \multicolumn{1}{c}{ Fasilitas } & $\mathbf{m}^{2} /$ penumpang & LOS \\
\hline Curb Keberangkatan & 0,4 & $\mathrm{E}$ \\
Curb Kedatangan & 0,1 & $\mathrm{E}$ \\
Hall Keberangkatan & 0,3 & $\mathrm{E}$ \\
Hall Kedatangan & 0,2 & $\mathrm{E}$ \\
Check-in Area & 1,3 & $\mathrm{C}$ \\
Ruang Tunggu Keberangkatan Lantai 1 & & \\
Berdasarkan luas gedung terminal & 1,6 & $\mathrm{C}$ \\
Berdasarkan jumlah penumpang berdiri & 2,5 & $\mathrm{~A}$ \\
Ruang Tunggu Keberangkatan Lantai 2 & & \\
Berdasarkan luas gedung terminal & 0,9 & $\mathrm{E}$ \\
Berdasarkan jumlah penumpang berdiri & 0,6 & $\mathrm{E}$ \\
Gate Hold Room & 0,7 & $\mathrm{D}$ \\
Baggage Claim Area & 0,6 & $\mathrm{E}$ \\
\hline Sugr: Hasil Analisis (2021)
\end{tabular}

Sumber: Hasil Analisis (2021) 
Sesuai dengan Tabel 4, diketahui bahwa fasilitas eksisting yang ada dalam terminal penumpang Bandar Udara Sentani pada saat ini seperti ruang tunggu lantai 2, sirkulasi, dan baggage claim area memperoleh nilai yang sangat rendah yaitu LOS (E), untuk fasilitas lainnya seperti gate hold room memperoleh nilai LOS (D), check-in area dan ruang tunggu lantai 1 (berdasarkan luas bangunan) memperoleh nilai LOS $(\mathrm{C})$, sedangkan ruang tunggu lantai 1 (berdasarkan jumlah penumpang berdiri) masih dalam kondisi sangat baik dengan perolehan nilai LOS (A).

\subsection{Standar Pelayanan Pengguna Jasa Bandar Udara Sentani}

Standar pelayanan pengguna jasa bandar udara berdasarkan PM 178 Tahun 2015 yang disesuaikan dengan kondisi eksisting terminal penumpang Bandar Udara Sentani yaitu sebanyak 21 atribut sesuai standar sedangkan 18 atribut tidak sesuai standar dengan nilai persentase seperti pada Gambar 2

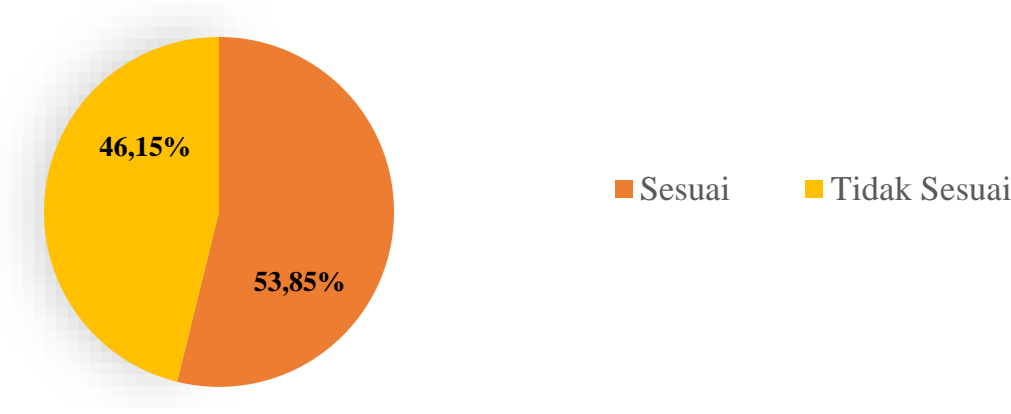

Gambar 2. Pie Chart Tingkat Kesesuaian Standar Pelayanan Jasa Bandar Udara Sentani

Berdasarkan Gambar 2, diperoleh presentase kesesuaian pelayanan jasa kondisi aktual dengan standar yang digunakan sebesar 53,85\% sedangkan yang belum/tidak sesuai sebesar $46,15 \%$.

\subsection{Pengujian Kuesioner Tingkat Pelayanan Jasa Bandar Udara Sentani}

\subsubsection{Uji Validitas}

Pengujian validitas sampel dengan $\mathrm{n}$ (banyak sampel) sebanyak 112 responden dan $\alpha=10 \%$ memperoleh nilai $r_{\text {tabel }}$ sebesar 0,1548. Dari perbandingan $r_{\text {perhitungan }}$ atribut kepentingan dan $r_{\text {perhitungan }}$ atribut kepuaan/kinerja dengan $r_{\text {tabel}}$, didapatkan hasil seluruh atribut pelayanan jasa Bandar Udara Sentani dalam kuesioner tersebut valid karena nilai $r_{\text {perhitungan }}>r_{\text {tabel }}$. Hasil perhitungan uji validitas dilakukan menggunakan program SPSS 25.0 for Windows.

\subsubsection{Uji Reliabilitas}

Hasil analisis uji reliabilitas instrumen kepentingan dan kepuasan pelayanan jasa Bandar Udara Sentani dengan program SPSS 25.0 for Windows yaitu reliable karena nilai Cronbach Alpha hasil uji atribut kepentingan sebesar 0,952 > 0,6 dan nilai Cronbach Alpha hasil kepuasan/kinerja sebesar $0,942>0,6$.

\subsection{Analisis Importance Performance Analysis (IPA)}

Dari analisis IPA terhadap tingkat kepentingan dan tingkat kinerja/kepuasan pelayanan jasa berdasarkan persepsi penumpang atau pengguna jasa Bandar Udara Sentani, diperoleh atribut-atribut pelayanan yang terbagi menjadi 4 kuadran yang dapat dilihat pada Gambar 3, 


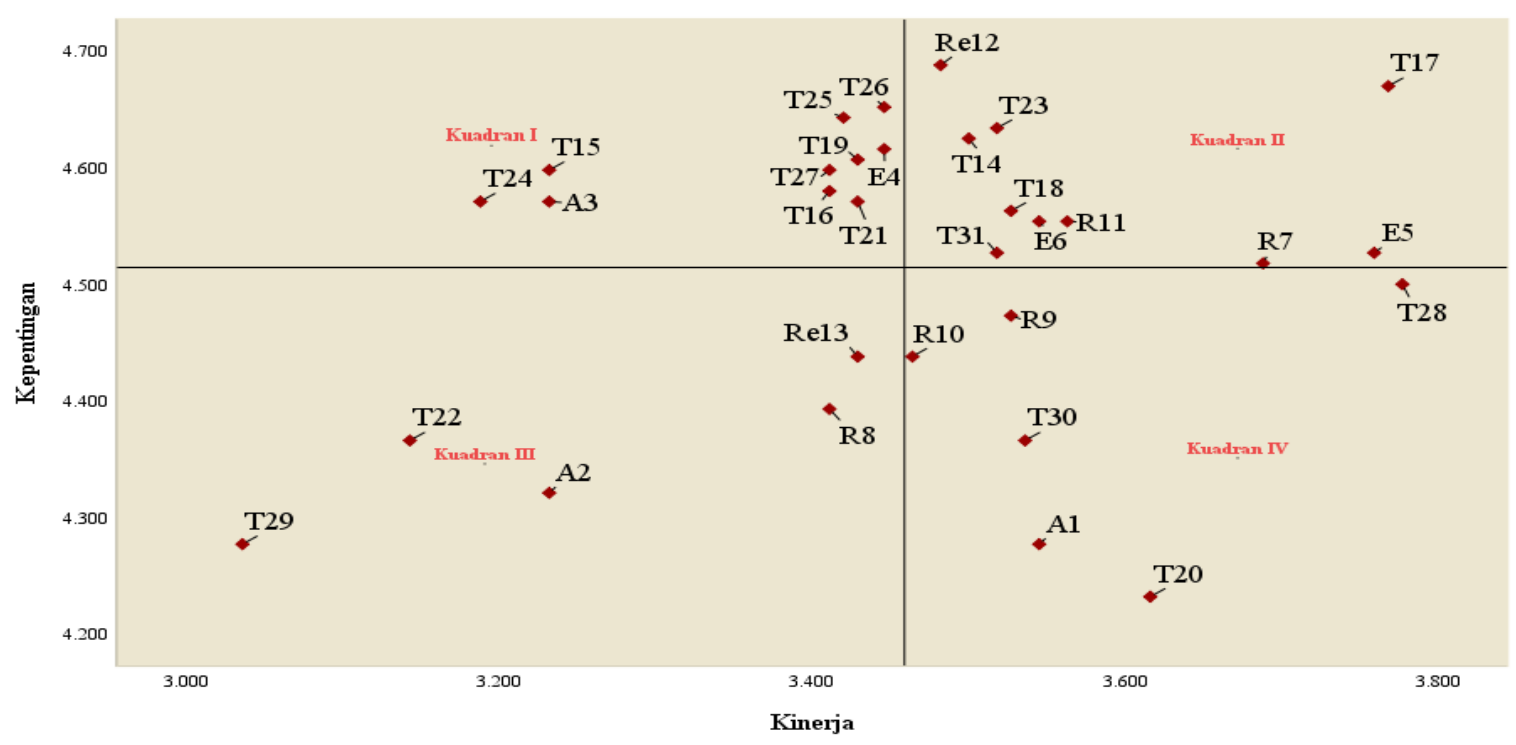

Gambar 3. Diagram Kartesius Importance Performance Analysis (IPA)

Sesuai dengan diagram kartesius IPA, atribut yang terbagi ke dalam masing-masing kuadran dapat diuraikan sebagai berikut:

1. Kuadran I (Prioritas Utama)

Pada kuadaran ini, terdapat aspek-aspek yang dinilai penting dan/atau diharapkan oleh penumpang sekaligus pengguna jasa terminal penumpang Bandar Udara Sentani akan tetapi kinerja dari perusahaan penyedia jasa belum memuaskan. Atribut-atribut yang tergolong ke dalam kuadran I adalah sebagai berikut:

- Atribut A3 : Jaminan ganti rugi kehilangan barang dalam bagasi.

- Atribut E4 : Kemudahan pengangkutan bagasi dengan menggunakan trolley yang tersedia.

- $\quad$ Atribut T15 : Ketersediaan sarana kelengkapan di dalam toilet.

- Atribut T16 : Kapasitas lahan parkir kendaraan penumpang/pengunjung bandar udara luas dan memadai.

- $\quad$ Atribut T19 : Menyediakan tempat untuk berbelanja yang lengkap.

- $\quad$ Atribut T21 : Ruangan khusus/terpisah yang digunakan untuk merokok.

- Atribut T24 : Internet/wifi dapat terhubung dan digunakan untuk membuka internet.

- Atribut T25 : Disediakan komputer khusus untuk membeli tiket secara online.

- Atribut T26 : Charging station dapat berfungsi dengan baik untuk mengisi daya elektronik.

- $\quad$ Atribut T27 : Penyejuk ruangan (AC/kipas angin) untuk menjaga suhu ruangan tetap stabil.

2. Kuadran II (Pertahankan Prestasi)

Pada kuadaran ini, terdapat aspek-aspek yang dirasa penting dan telah sesuai dengan kepuasan serta kepentingan pengguna jasa terminal penumpang Bandar Udara Sentani sehingga perusahaan penyedia jasa wajib untuk menjaga dan mempertahankan kinerja tersebut. Atributatribut yang tergolong ke dalam kuadran II adalah sebagai berikut:

- Atribut E5 : Layanan informasi tersampaikan dengan jelas untuk penumpang.

- Atribut E6 : Penumpang disabilitas mudah berkomunikasi dengan pihak bandar udara. 
- $\quad$ Atribut R7 : Petugas bandar udara melayani proses check-in dengan sigap.

- $\quad$ Atribut R11 : Penumpang disabilitas dilayani dengan tanggap oleh petugas.

- Atribut Re12 : Jadwal keberangkatan pesawat tepat waktu.

- Atribut T14 : Seluruh area bandar udara terjaga kebersihannya oleh petugas kebersihan.

- $\quad$ Atribut T17 : Tersedia tempat beribadah (musholla) yang nyaman.

- $\quad$ Atribut T18 : Terdapat ruangan khusus untuk ibu menyusui (nursery)

- Atribut T23 : ATM/money changer dapat dijangkau dan digunakan untuk melakukan transaksi uang.

- $\quad$ Atribut T31 : Lift dan toilet khusus yang digunakan untuk penumpang disabilitas.

3. Kuadran III (Prioritas Rendah)

Pada kuadaran ini, terdapat aspek-aspek yang dirasa tidak terlalu penting dan/atau tidak terlalu diharapkan oleh pengguna jasa terminal penumpang Bandar Udara Sentani karena kinerja yang dihasilkan cukup atau biasa saja sehingga perusahaan tidak perlu menaruh perhatian lebih terhadap hal-hal tersebut. Atribut-atribut yang tergolong ke dalam kuadran III adalah sebagai berikut:

- $\quad$ Atribut A2 : Kompensasi cancel keberangkatan (penginapan, uang, dan lain-lain).

- Atribut R8 : Bantuan cepat dari petugas dalam penyerahan bagasi pertama dan terakhir.

- $\quad$ Atribut Re13 : Biaya over bagasi sesuai degan berat bagasi.

- Atribut T22 : Ruang bermain anak yang bersih, nyaman, dan dalam pengawasan.

- $\quad$ Atribut T29 : Tersedianya fasilitas air minum gratis maupun berbayar.

4. Kuadran IV (Berlebihan)

Pada kuadaran ini, terdapat aspek-aspek yang dirasa tidak terlalu penting dan tidak terlalu diharapkan oleh pengguna jasa terminal penumpang Bandar Udara Sentani, kinerja dari perusahaan jasa sangat baik dan memuaskan namun menjadi lebih tidak efisien. Atribut-atribut yang tergolong ke dalam kuadran IV adalah sebagai berikut:

- Atribut A1 : Waktu pemeriksaan penumpang dan bagasi dilakukan dengan cepat.

- Atribut R9 : Pemeriksaan penumpang pada imigrasi keberangkatan/kedatangan dilakukan dengan baik.

- $\quad$ Atribut R10 : Pemrosesan bea cukai dilakukan sesuai dengan prosedur.

- Atribut T20 : Adanya sarana yang menjual belikan makanan dan minuman untuk penumpang.

- $\quad$ Atribut T28 : Pencahayan dari lampu yang terang di setiap ruangan dalam terminal bandar udara.

- $\quad$ Atribut T30 : Memiliki ruang tunggu eksekutif bagi penumpang khusus.

\subsection{Analisis Quality Function Deployment (QFD)}

Tahap-tahap serta uraian pengolahan data Quality Function Deployment adalah sebagai berikut:

\section{a. Voice of Customer}

Dalam menentukan suara dari penumpang, digunakan atribut pelayanan pada kuadran I analisis metode IPA (Importance Performance Analysis) yang mana atribut-atribut tersebut mempunyai tingkat kinerja pelayanan yang rendah namun dinilai sangat penting bagi pengguna jasa terminal penumpang Bandar Udara Sentani.

\section{b. Matriks Perencanaan}

Dalam menyusun matriks perencanaan dalam penelitian ini, terdapat beberapa tahap pengolahan data dengan hasil rekapan seperti yang ditunjukkan pada Tabel 5. 
Tabel 5. Rekapan Hasil Perhitungan Tahap Pengolahan Data Matriks Perencanaan

\begin{tabular}{|c|c|c|c|c|c|c|c|}
\hline No. & $\begin{array}{c}\text { Atribut (Kuadran I } \\
\text { Importance Performance } \\
\text { Analysis) }\end{array}$ & $\begin{array}{c}\text { Importance } \\
\text { to } \\
\text { Customer }\end{array}$ & $\begin{array}{c}\text { Customer } \\
\text { Satisfaction } \\
\text { Performance }\end{array}$ & Goal & $\begin{array}{c}\text { Improvement } \\
\text { Ratio }\end{array}$ & $\begin{array}{c}\text { Raw } \\
\text { Weight }\end{array}$ & $\begin{array}{l}\text { Normalized } \\
\text { Raw Weight }\end{array}$ \\
\hline 3 & $\begin{array}{l}\text { Jaminan ganti } \quad \text { rugi } \\
\text { kehilangan barang } \\
\text { bagasi. }\end{array}$ & 4.571 & 3.232 & 4.571 & 1.414 & 6.465 & 0.103 \\
\hline 4 & $\begin{array}{l}\text { Kemudahan pengangkutan } \\
\text { bagasi dengan } \\
\text { menggunakan trolley yang } \\
\text { tersedia. }\end{array}$ & 4.616 & 3.446 & 4.616 & 1.340 & 6.183 & 0.098 \\
\hline 15 & $\begin{array}{l}\text { Ketersediaan } \\
\text { kelengkapan di } \\
\text { toilet. }\end{array}$ & 4.598 & 3.232 & 4.598 & 1.423 & 6.541 & 0.104 \\
\hline 16 & $\begin{array}{l}\text { Kapasitas lahan parkir } \\
\text { kendaraan } \\
\text { penumpang/pengunjung } \\
\text { bandar udara luas dan } \\
\text { memadai. }\end{array}$ & 4.580 & 3.411 & 4.580 & 1.343 & 6.150 & 0.098 \\
\hline 19 & $\begin{array}{l}\text { Menyediakan tempat } \\
\text { untuk berbelanja yang } \\
\text { lengkap. }\end{array}$ & 4.607 & 3.429 & 4.607 & 1.344 & 6.190 & 0.098 \\
\hline 21 & $\begin{array}{l}\text { Ruangan khusus/terpisah } \\
\text { yang digunakan untuk } \\
\text { merokok. }\end{array}$ & 4.571 & 3.429 & 4.571 & 1.333 & 6.093 & 0.097 \\
\hline 24 & $\begin{array}{l}\text { Internet/wifi dapat } \\
\text { terhubung dan digunakan } \\
\text { untuk membuka internet. }\end{array}$ & 4.571 & 3.188 & 4.571 & 1.434 & 6.554 & 0.104 \\
\hline 25 & $\begin{array}{l}\text { Disediakan komputer } \\
\text { khusus untuk membeli } \\
\text { tiket secara online. }\end{array}$ & 4.643 & 3.420 & 4.643 & 1.358 & 6.303 & 0.100 \\
\hline 26 & $\begin{array}{l}\text { Charging station } \\
\text { berfungsi dengan } \\
\text { untuk mengisi } \\
\text { elektronik. }\end{array}$ & 4.652 & 3.446 & 4.652 & 1.350 & 6.280 & 0.100 \\
\hline 27 & $\begin{array}{l}\text { Penyejuk ruangan } \\
\text { (AC/kipas angin) untuk } \\
\text { menjaga suhu ruangan } \\
\text { tetap stabil. }\end{array}$ & 4.598 & 3.411 & 4.598 & 1.348 & 6.198 & 0.098 \\
\hline
\end{tabular}

Sumber: Hasil Perhitungan (2021).

Berdasarkan Tabel 5, dapat diketahui hasil dari masing-masing tahapan yaitu Importance to Customer yang diperoleh dari nilai rata-rata tingkat kepentingan atribut tersebut, Customer Satisfaction Performance dari nilai rata-rata tingkat kinerja/kepuasan atribut tersebut, goal (sasaran) dari nilai tertinggi antara rata-rata kepentingan dengan kinerja/kepuasan atribut tersebut, improvement ratio dari perbandingan nilai goal dengan CuSP, raw weight dari perkalian antara nilai ItC dengan improvement ratio, dan Normalized Raw Weight dari perbandingan antara nilai raw weight dengan total nilai raw weight sebesar 62,957.

\section{c. Respon Teknis}

Hasil dari respon teknis diperoleh dari wawancara kepada pihak PT. Angkasa Pura I selaku pihak pengelola terminal penumpang Bandar Udara Sentani. 


\section{d. Relationship Matrix}

Matrik hubungan antara atribut pernyataan dengan respon teknis dapat diperoleh melalui penilaian menggunakan simbol yaitu $(\Delta)$ untuk hubungan lemah, ( $(0)$ untuk hubungan sedang dan $(\bullet)$ untuk hubungan kuat yang dapat dilihat pada Gambar 4.

\section{e. Correlation Matrix}

Correlation matrix diperoleh dari analisis keterkaitan antar respon teknis menggunakan simbol (+) untuk hubungan positif, (-) untuk hubungan negatif dan (++) untuk hubungan sangat positif yang dapat dilihat pada Gambar 4.

\section{f. Technical Matrix}

Technical matrix diperoleh dengan perhitungan nilai prioritas teknik yang diperoleh dari total nilai contributions. Setelah itu, dihitung nilai normalized constributions untuk menentukan prioritas perbaikan dengan rekapan yang diuraikan dalam Gambar 4.

\section{g. House of Quality (HOQ)}

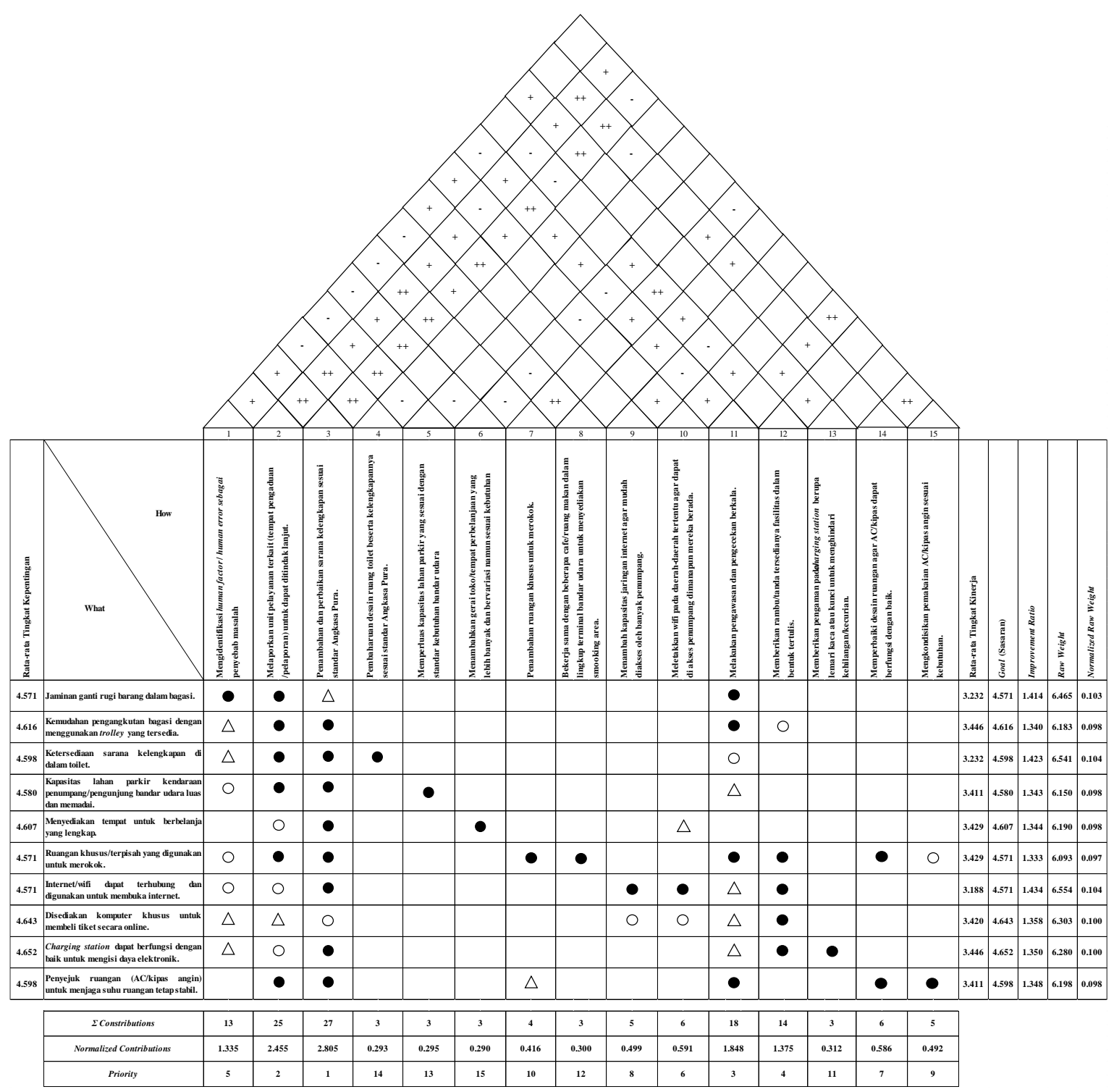

Gambar 4. House of Quality (HOQ) 
Pada matrik House of Quality dalam Gambar 4, diketahui bentuk realisasi metode Quality Function Deployment dengan prioritas utama perbaikan yaitu penambahan dan perbaikan sarana kelengkapan sesuai standar Angkasa Pura, kemudian melaporkan unit pelayanan terkait (tempat pengaduan/pelaporan) untuk dapat ditindak lanjut, melakukan pengawasan dan pengecekan berkala, memberikan rambu/tanda tersedianya charging station, mengidentifikasi human factor/human error penyebab masalah, meletakkan wifi pada area tertentu agar dapat diakses penumpang, memperbaiki desain ruangan agar AC/kipas angin dapat berfungsi dengan baik, menambah kapasitas jaringan internet, mengkondisikan pemakaian AC/kipas angin sesuai kebutuhan, penambahan ruang khusus merokok, memberikan pengaman pada charging station berupa lemari kaca dengan kunci, bekerja sama dengan pihak cafe/restaurant untuk menyediakan smooking area, memperluas kapasitas lahan parkir, pembaharuan desain toilet beserta kelengkapannya sesuai standar Angkasa Pura, dan menambahkan tempat berbelanja yang lebih lengkap.

\subsection{Re-design Terminal Penumpang Bandar Udara Sentani}

Berdasarkan hasil analisa data, terminal penumpang Bandar Udara Sentani perlu melakukan perencanaan dan pengelolaan kembali area terminal dengan fasilitas kelengkapan yang ada di dalamnya. Bentuk re-design dari terminal penumpang adalah seperti pada Gambar 6 .
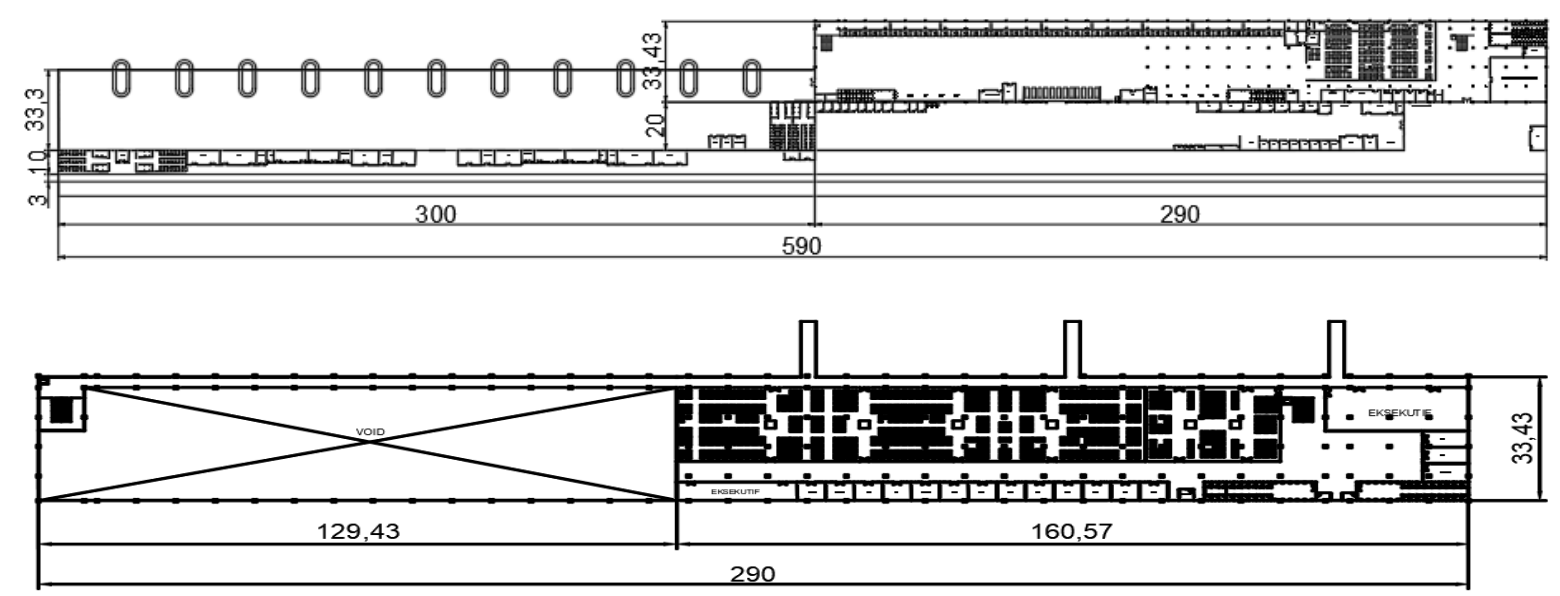

Gambar 5. Re-design 1 Terminal Penumpang Bandar Udara Sentani (Lantai 1 dan 2)
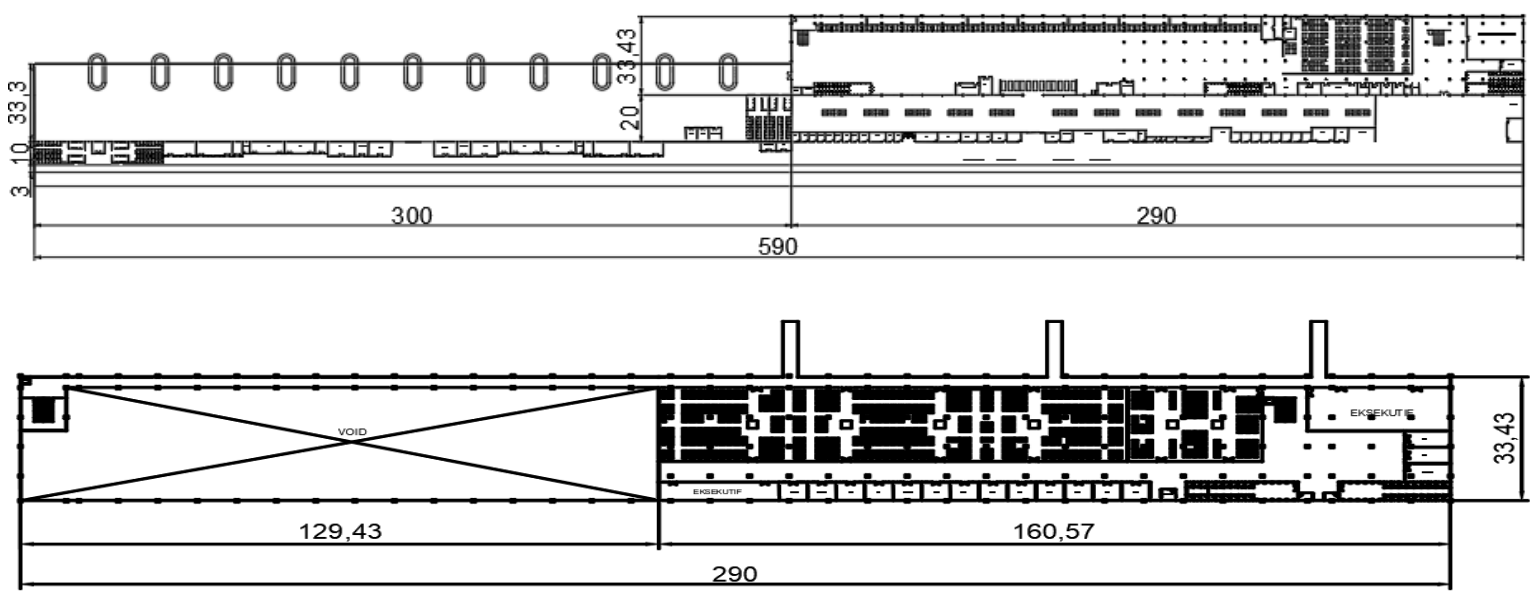

Gambar 6. Re-design 2 Terminal Penumpang Bandar Udara Sentani (Lantai 1 dan 2) 
dari Gambar 5 dan 6, diketahui area terminal penumpang Bandar Udara Sentani yang telah direncanakan ulang dalam bentuk perluasan seluruh area (kecuali check-in area dan ruang tunggu keberangkatan lantai 1), perbaikan pada tata letak ruangan, dan perubahan bentuk ruang tunggu keberangkatan (lantai 1 dan 2) menjadi satu ruangan terpusat dalam ruang kaca. Di dalam terminal, penambahan beberapa fasilitas penunjang juga dilakukan untuk jumlah $x$-ray pada pemeriksaan security (terpusat), jumlah dan konfigurasi counter check-in, kapasitas kursi ruang tunggu keberangkatan lantai 1 dan 2, dan jumlah baggage claim device. Di sisi lain, beberapa area dengan sarana yang ditambahkan atas harapan dari pengguna jasa terminal yaitu area trolley dengan ketersediaan alatnya, area charging station, ruang khusus merokok (smooking area), kapasitas lahan parkir kendaraan umum, tempat berbelanja yang lebih lengkap, area khusus dengan komputer pembelian tiket online, dan perubahan desain atap terminal agar AC/kipas angin dapat berfungsi dengan baik. Untuk bagian pelayanan, dilakukan perbaikan pada jaminan ganti rugi kehilangan barang dalam bagasi, ketersediaan sarana dalam toilet, dan kelancaran fungsi internet/wifi.

\subsection{Forecasting/Peramalan Pergerakan Penumpang}

Peramalan dalam penelitian ini menggunakan variabel bebas berupa data pergerakan penumpang pada tahun 2012-2020 dari (PT. Angkasa Pura I, 2021) Seperti pada Tabel 6,

Tabel 6. Pergerakan Penumpang Tahun 2012-2020

\begin{tabular}{cccccc}
\hline & & \multicolumn{3}{c}{ Pergerakan Penumpang di Bandar Udara Sentani Jayapura } \\
\cline { 3 - 6 } No. & Tahun & $\begin{array}{c}\text { Datang } \\
\text { (orang) }\end{array}$ & $\begin{array}{c}\text { Berangkat } \\
\text { (orang) }\end{array}$ & $\begin{array}{c}\text { Transfer } \\
\text { (orang) }\end{array}$ & Total (orang) \\
\hline 1 & 2012 & 563304 & 711245 & 110505 & 1385054 \\
2 & 2013 & 618554 & 844533 & 165554 & 1628641 \\
3 & 2014 & 635074 & 885897 & 196866 & 1717810 \\
4 & 2015 & 643020 & 913514 & 203003 & 1759536 \\
5 & 2016 & 695057 & 868821 & 139011 & 1737643 \\
6 & 2017 & 880822 & 1101028 & 176164 & 2202056 \\
7 & 2018 & 1058522 & 1077945 & 200862 & 2337329 \\
8 & 2019 & 848463 & 871544 & 139690 & 1859697 \\
9 & 2020 & 631856 & 638507 & 100234 & 1370597 \\
\hline
\end{tabular}

Sumber: PT. Angkasa Pura I, Bandar Udara Sentani (2021).

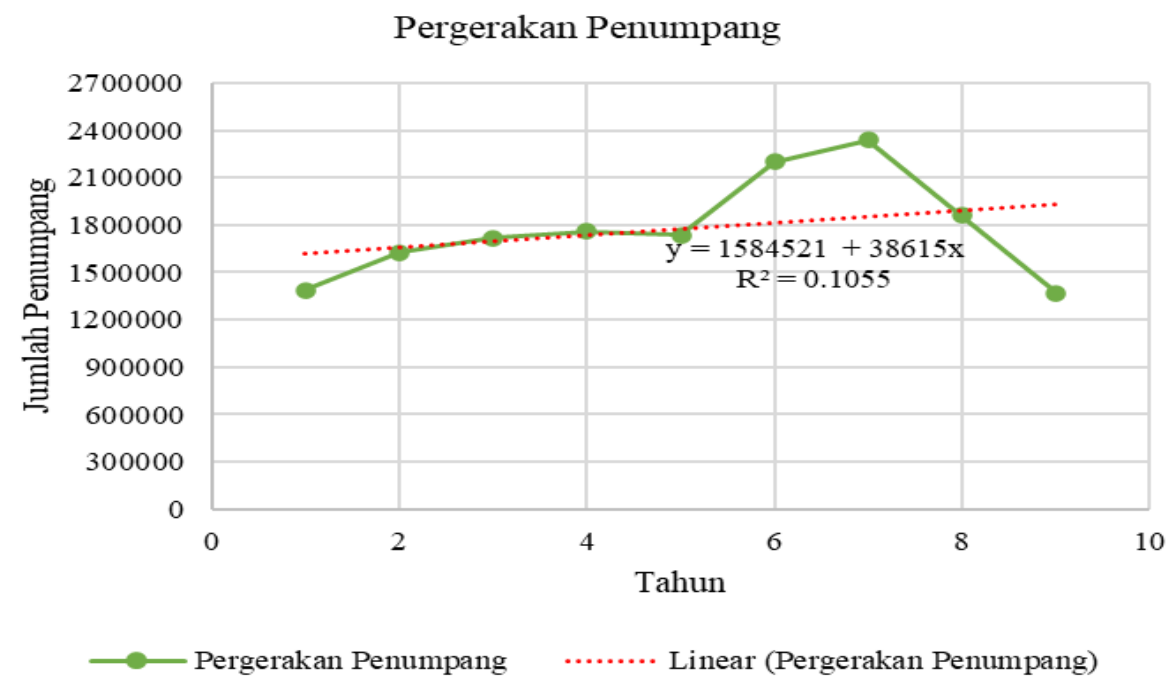

Gambar 7. Grafik Regresi Linier Pergerakan Penumpang (2012-2020) 
Dari uraian pergerakan penumpang pada Tabel 6, dilakukan peramalan jumlah pergerakan penumpang untuk jangka waktu 5 tahun kedepan (2021-2025) menggunakan metode regresi linier sederhana karena pola data yang tersedia berupa trend linier (data penumpang naik dan turun), dengan grafik yang dihasilkan seperti yang ditunjukkan pada Gambar 7.

Berdasarkan korelasi persamaan regresi linier pergerakan penumpang di Bandar Udara Sentani yang diolah dengan bantuan Microsoft Excel pada Gambar 7, maka persamaan yang digunakan yaitu:

$Y=a+b x$

Sehingga perhitungan peramalan adalah sebagai berikut:

$\mathrm{Y}=\mathrm{a}+\mathrm{bx}$

$Y=1584521+(38615)(5)$

$\mathrm{Y}=1777596$ penumpang/tahun

Dari hasil perhitungan, diperoleh forecasting jumlah penumpang pada tahun 2025 sebanyak 1777596 orang. Data tersebut digunakan untuk menghitung jumlah PWS lalu menghitung kebutuhan kapasitas rencana terminal penumpang Bandar Udara Sentani yang dapat dilihat pada Tabel 7.

Tabel 7. Hasil Perhitungan Kapasitas Rencana Terminal Penumpang Bandar Udara Sentani

\begin{tabular}{clccc}
\hline No. & \multicolumn{1}{c}{ Fasilitas } & Eksisting & Evaluasi & Tahun 2025 \\
\hline 1. & Curb Keberangkatan & $1258 \mathrm{~m}^{2}$ & $2900 \mathrm{~m}^{2}$ & $840 \mathrm{~m}^{2}$ \\
2. & Curb Kedatangan & $422 \mathrm{~m}^{2}$ & $3000 \mathrm{~m}^{2}$ & $840 \mathrm{~m}^{2}$ \\
3. & Hall Keberangkatan & $2770 \mathrm{~m}^{2}$ & $8154 \mathrm{~m}^{2}$ & $2347 \mathrm{~m}^{2}$ \\
4. & Hall Kedatangan & $1163 \mathrm{~m}^{2}$ & $6836 \mathrm{~m}^{2}$ & $1907 \mathrm{~m}^{2}$ \\
5. & Pemeriksaan Security (Terpusat) & $2 \mathrm{unit}$ & $12 \mathrm{unit}^{2}$ & 4 unit \\
6. & Check-in Area & $1374 \mathrm{~m}^{2}$ & $1023 \mathrm{~m}^{2}$ & $293 \mathrm{~m}^{2}$ \\
7. & Counter Check-in & 30 counters & 136 counters $^{2}$ & 39 counters \\
8. & Area Custom Immigration Quarantine & $67,84 \mathrm{~m}^{2}$ & $956 \mathrm{~m}^{2}$ & $267 \mathrm{~m}^{2}$ \\
9. & Ruang Tunggu Keberangkatan & $3422 \mathrm{~m}^{2}$ & $3188 \mathrm{~m}^{2}$ & $887 \mathrm{~m}^{2}$ \\
10. & Gate Hold Room & $139 \mathrm{~m}^{2}$ & $189 \mathrm{~m}^{2}$ & $189 \mathrm{~m}^{2}$ \\
11. & Toilet Keberangkatan & $274,34 \mathrm{~m}^{2}$ & $678 \mathrm{~m}^{2}$ & $196 \mathrm{~m}^{2}$ \\
12. & Toilet Kedatangan & $193 \mathrm{~m}^{2}$ & $701 \mathrm{~m}^{2}$ & $196 \mathrm{~m}^{2}$ \\
13. & Baggage Claim Area & $1988 \mathrm{~m}^{2}$ & $3155 \mathrm{~m}^{2}$ & $880 \mathrm{~m}^{2}$ \\
14. & Baggage Claim Device & $3 \mathrm{unit}^{2}$ & $11 \mathrm{unit}^{2}$ & 3 unit $^{2}$ \\
\hline
\end{tabular}

Sumber: Hasil Perhitungan (2021).

Berdasarkan hasil perhitungan yang diuraikan dalam Tabel 7, diperoleh prediksi kapasitas terminal penumpang Bandar Udara Sentani untuk 5 tahun kedepan (tahun 2025) masih dapat memenuhi standar dan memberi akses gerak bagi penumpang pada waktu sibuk.

\section{Kesimpulan}

Terminal penumpang Bandar Udara Sentani pada saat ini dinyatakan kurang maksimal dalam memberi akses gerak apabila terjadi lonjakan penumpang khususnya menampung Penumpang Waktu Sibuk (PWS) yang ditinjau dari hasil perhitungan luas teoritis terminal. Nilai Level of Service (LOS) fasilitas terminal penumpang Bandar Udara Sentani sebagian besar dalam kondisi tingkat pelayanan yang tidak dapat diterima (sangat rendah). Kinerja pelayanan aktual terminal penumpang Bandar Udara Sentani berdasarkan persepsi penumpang dinyatakan masih kurang maksimal untuk memberikan pelayanan dibeberapa aspek. Prioritas utama perbaikan dalam aspek jaminan ganti rugi kehilangan barang dalam bagasi, kemudahan pengangkutan bagasi dengan trolley, ketersediaan 
sarana dalam toilet, kapasitas lahan parkir kendaraan penumpang/pengunjung, tempat berbelanja yang lengkap, ruangan khusus merokok, internet/wifi dapat berfungsi dengan baik, tersedia komputer untuk membeli tiket online, charging station, dan penyejuk ruangan (AC/kipas angin) yang berfungsi dengan baik. Penanganan utama yang dapat dilakukan oleh pihak pengelola bandara berupa penambahan dan perbaikan sarana kelengkapan sesuai standar Angkasa Pura. Rekomendasi desain terminal penumpang Bandar Udara Sentani dalam bentuk perluasan area dengan penambahan sarana kelengkapannya, perbaikan tata letak ruangan, perubahan bentuk ruang tunggu keberangkatan (lantai 1 dan 2) menjadi satu ruangan terpusat dalam ruangan kaca, penambahan luas lahan parkir kendaraan umum, penambahan tempat berbelanja, ruangan khusus merokok, penambahan area penyimpanan trolley, area khusus komputer tiket online, area charging station, dan re-design atap terminal untuk memaksimalkan kerja AC/kipas angin. Dari hasil re-design tersebut, diprediksi terminal penumpang Bandar Udara Sentani tidak perlu melakukan pengembangan fasilitas sisi darat (land side) untuk jangka waktu 5 tahun kedepan.

\section{Daftar Pustaka}

Arifin, A. S., Sulistyo, H., \& Djakfar, L. (2015). Kajian Kepuasan Penumpang Terhadap Kinerja Pelayanan Maskapai Penerbangan Rute Surabaya-Jakarta (Studi Kasus : Bandar Udara Internasional Juanda Surabaya). 7, 13-22.

Badan Standardisasi Nasional. (2004). SNI Terminal Penumpang Bandar Udara. SNI 03-704(4), 154-160.

Bakri, M. D., \& Christin, F. (2019). Evaluasi Kapasitas Terminal Penumpang Bandar Udara Juwata Tarakan. Jurnal Borneo Saintek, Volume 2.

Clarke, Jhonson, E. L., Solak, S., \& B, J. P. (2009). Airport Terminal Capacity Planning. Transportation Research Part B: Methodological, Volume 43.

International Civil Aviation Organization. (2000). Standards, International Practices, Recommended The, $\mathrm{T}$ O On, Convention Civil, International Design, Aerodrome. International Organization ISSN: $15315088,7(3), 412-414$.

Kementerian Perhubungan Republik Indonesia. (2015). Peraturan Menteri Perhubungan Republik Indonesia No.185 tahun 2015. Kementerian Perhubungan Republik Indonesia, 13. Jakarta.

Mariana, I. K. O., Sulistio, H., \& Arifin, M. Z. (2015). Kajian Tingkat Kepuasan Penumpang Dan Kinerja Pelayanan Terminal Penumpang Domestik (T2) Di Bandar Udara Internasional Juanda Surabaya. Jurnal Rekayasa Sipil, 9(3), 168-178.

Menteri Perhubungan Republik Indonesia. (2015). PM 178 Tahun 2015 Tentang Standar Pelayanan Pengguna Jasa Bandar Udara. Jakarta.

Peraturan Direktur Jendral Perhubungan Udara. (2005). SKEP 77-VI-2005 Tentang Persyaratan Teknis Pengoperasian Fasilitas Teknik Bandar Udara. Jakarta.

Presiden Republik Indonesia. (2009). Undang-Undang No.1 Tahun 2009 Tentang Penerbangan. Jakarta.

PT. Angkasa Pura I. (2021). Data Traffic Penumpang Tahun 2012-2020 Bandar Udara Sentani.

Pusat Pengembangan Kawasan Perkotaan, B. P. I. W. (2017). Profil Kota Jayapura. Retrieved from http://perkotaan.bpiw.pu.go.id/n/kota-otonom/66.

Riki Tri Alfian, \& Widyastuti, H. (2013). Evaluasi Kinerja Terminal Penumpang 1A Bandar Udara Internasioanl Soekarno-Hatta. TEKNIK POMITS, 1, No. 1, 1-4. 
Sompotan, W. G. (2018). Evaluasi Kapasitas Terminal Penumpang Bandar Udara Internasional Ahmad Yani Semarang. Universitas Trisakti.

Tulungen, B. B. (2016). Perencanaan Pengembangan Bandar Udara Melonguane Kabupaten Kepulauan Talaud Provinsi Sulawesi Utara. Jurnal Sipil Statik Vol.4 No.1 Januari 2016 (1-12) ISSN: 2337-6732, 4(1), 484-495.

Wahyudi, J., Arifin, M. Z., \& Wicaksono, A. D. (2016). Kajian Kinerja Pelayanan Terminal Penumpang Domestik Bandar Udara Kelas 1 Utama Juwata Tarakan. Rekayasa Sipil, 10(2), $136-145$. 